Low mol ecul ar wei ght hepar i n suppresses recept or for advanced gl ycat i on end product s- medi at ed expressi on of mal i gnant phenotype i n human fi br osar cona cel I s

\begin{tabular}{|c|c|}
\hline 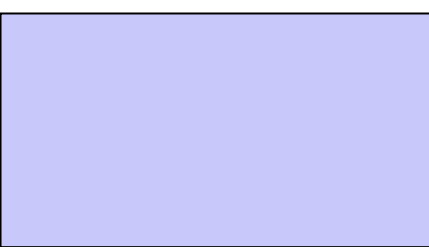 & $\begin{array}{l}\text { Takeuchi Aki hi ko, Yamanto o Yasuhi ko, Minesue } \\
\text { Sei i chi, Har ashi ma Ai, Wat anabe Takuo, } \\
\text { Yonekur a Hi det o, Yamant o H r roshi, Tsuchi ya } \\
\text { H r oyuki }\end{array}$ \\
\hline 著者別表示 & $\begin{array}{l}\text { 武内 章彦, 山本 靖彦, 棟居 聖一, 原島 愛, 渡邊 } \\
\text { 玩夫, 米倉 秀人, 山本 博, 土屋 弘行 }\end{array}$ \\
\hline $\begin{array}{l}\text { j our nal or } \\
\text { publ i cat i on titl e }\end{array}$ & Cancer Sci ence \\
\hline vol une & 104 \\
\hline number & 6 \\
\hline page $r$ ange & $740-749$ \\
\hline year & $2013-06-01$ \\
\hline URL & ht t p: //doi . or g/10. 24517/00014342 \\
\hline
\end{tabular}




\title{
Low molecular weight heparin suppresses receptor for advanced glycation end products-mediated expression of malignant phenotype in human fibrosarcoma cells
}

\author{
Akihiko Takeuchi, ${ }^{1,4}$ Yasuhiko Yamamoto, ${ }^{2,4}$ Seiichi Munesue, ${ }^{2}$ Ai Harashima, ${ }^{2}$ Takuo Watanabe, ${ }^{2}$ \\ Hideto Yonekura, ${ }^{3}$ Hiroshi Yamamoto ${ }^{2}$ and Hiroyuki Tsuchiya ${ }^{1}$
}

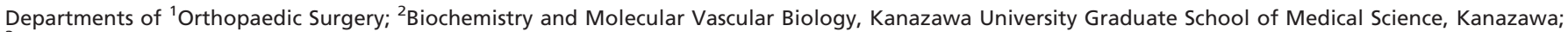
${ }^{3}$ Department of Biochemistry, Kanazawa Medical University, Uchinada, Japan

(Received October 29, 2012/Revised February 11, 2013/Accepted February 15, 2013/Accepted manuscript online February 19, 2013/Article first published online March 24, 2013)

\begin{abstract}
The receptor for advanced glycation end products (RAGE) is a pattern-recognition receptor and its engagement by ligands such as high mobility group box 1 (HMGB1) is implicated in tumor growth and metastasis. Low molecular weight heparin (LMWH) has an antagonistic effect on the RAGE axis and is also reported to exert an antitumor effect beyond the known activity of anticoagulation. However, the link between the anti-RAGE and antitumor activities of LMWH has not yet to be fully elucidated. In this study, we investigated whether LMWH could inhibit tumor cell proliferation, invasion, and metastasis by blocking the RAGE axis using in vitro and in vivo assay systems. Stably transformed HT1080 human fibrosarcoma cell lines were obtained, including human full-length RAGE-overexpressing (HT1080 $\left.{ }^{\text {RAGE}}\right)$, RAGE dominant-negative, intracellular tail-deleted RAGE-overexpressing (HT1080 $\left.{ }^{\text {dnRAGE }}\right)$, and mock-transfected control (HT1080 ${ }^{\text {mock}}$ ) cells. Confocal microscopy showed the expression of HMGB1 and RAGE in HT1080 cells. The LMWH significantly inhibited HMGB1induced NFKB activation through RAGE using an NFkB-dependent luciferase reporter assay and the HT1080 cell lines. Overexpression of RAGE significantly accelerated, but dnRAGE expression attenuated HT1080 cell proliferation and invasion in vitro, along with similar effects on local tumor mass growth and lung metastasis in vivo. Treatment with LMWH significantly inhibited the migration, invasion, tumor formation, and lung metastasis of HT1080 RAGE cells, but not of HT1080 mock or HT1080 dnRAGE cells. In conclusion, this study revealed that RAGE exacerbated the malignant phenotype of human fibrosarcoma cells, and that this exacerbation could be ameliorated by LMWH. It is suggested that LMWH has therapeutic potential in patients with certain types of malignant tumors. (Cancer Sci 2013; 104: 740-749)
\end{abstract}

eceptor for advanced glycation end products is a multiligand pattern-recognition receptor, having an extracellular region with one $\mathrm{V}$-type and two $\mathrm{C}$-type immunoglobulin-like domains, one transmembrane region, and a short $\mathrm{C}$-terminal intracellular stretch. ${ }^{(1,2)}$ The $\mathrm{V}$ domain of RAGE is critical for the binding of distinct ligands, such as $\mathrm{AGE}^{(1,2)} \mathrm{S} 100$ proteins, ${ }^{(3,4)} \beta$-amyloid, ${ }^{(5,6)} \mathrm{Mac} 1 / \mathrm{CD} 11 \mathrm{~b},{ }^{(7)}$ lipopolysaccharides, ${ }^{(8)}$ phosphatidylserine, ${ }^{(9)}$ and HMGB1. ${ }^{(10-12)}$ The interaction between RAGE and these ligands has been implicated in proinflammatory reactions, diabetic vascular complications, neurodegenerative disorders, and cancer. ${ }^{(1,13,14)}$ The ligation of RAGE is reported to cause the activation of multiple intracellular signaling pathways, including $\mathrm{Cdc} 42 / \mathrm{Rac} 1$, p38 MAP kinase, ${ }^{(15)} \mathrm{PKC},{ }^{(16)}$ and $\mathrm{NFKB},{ }^{(17)}$ as well as the production of reactive oxygen species. The biological outcomes are also known to be divergent among cell types or under different conditions. Concerning malignant tumors, the HMGB1-RAGE axis is reported to be involved in tumor growth, invasion, and metastasis. ${ }^{(10,18)}$ RAGE expression has been documented in human malignancies of the stomach, ${ }^{(19)}$ colon and rectum, ${ }^{(20)}$ prostate, ${ }^{(21)}$ lung, ${ }^{(20)}$ breast, $^{(20)}$ and bone. ${ }^{(22)}$

Soft tissue sarcomas are rare malignant tumors arising from mesenchymal tissues. Multiagent chemotherapy has improved both the survival rate and limb function in patients with certain mesenchymal malignant tumors, such as osteosarcoma ${ }^{(23)}$ and Ewing's sarcoma. ${ }^{(2)}$ Despite advances in chemotherapy regimens, however, high-grade soft tissue sarcoma remains a fatal disease with frequent distant metastases. ${ }^{(25-27)}$ To improve the prognosis of high-grade soft tissue sarcoma, new therapeutic strategies are needed for the suppression of cancer spread and metastasis.

In 1930, Goerner et al. ${ }^{(28)}$ first reported the inhibitory effect of heparin against the growth of transplanted tumor tissues. Subsequently, anticoagulant therapy with unfractionated heparin $^{(29-31)}$ or warfarin ${ }^{(32-34)}$ has come to be indicated for several types of cancers. Numerous subsequent studies confirmed that anticoagulant agents improve the overall survival of cancer patients. (28-33) Low molecular weight heparin is a fragmented and fractionated heparin consisting of short polysaccharide chains with anticoagulant activity. ${ }^{(35)}$ The effect of LMWH on the improvement of overall survival has also been shown in various types of cancers. ${ }^{(36-38)}$ Altinbas et al. ${ }^{(39)}$ reported that treatment with LMWH improved chemotherapy responsiveness and overall survival in small cell lung cancer. Several mechanisms other than anticoagulation have been proposed to underlie the antitumor activity of LMWH. ${ }^{(39)}$ Harvey et al. ${ }^{(40)}$ suggested that LMWH may have an antagonistic effect on CXCR4 in breast cancer cells and thus inhibit tumor cell metastasis. Our group reported that LMWH, dalteparin obtained by deaminative cleavage of heparin with nitrous acid, had an antagonistic effect on RAGE. ${ }^{(41)}$ Moreover, we reported its preventive and therapeutic effects on diabetic nephropathy in vivo. ${ }^{(41)}$ On the basis of these findings, we hypothesized that the antitumor activity of LMWH, at least in part, depends on the competitive inhibition of RAGE-ligand interaction.

In this study, we investigated whether LMWH could inhibit tumor cell proliferation, migration, invasion, and distant metastasis by blocking the RAGE axis in vitro and in vivo using wild-type RAGE- and dominant negative RAGE-overexpressing human fibrosarcoma HT1080 cell lines.

${ }^{4}$ To whom correspondence should be addressed.

E-mails: a_take@med.kanazawa-u.ac.jp; yasuyama@med.kanazawa-u.ac.jp 


\section{Materials and Methods}

Cell line. The HT1080 human fibrosarcoma cells (ATCC, Rockville, MD, USA) were transfected with a plasmid containing human full-length RAGE cDNA, cytoplasmic domain-deleted dominant negative RAGE cDNA, or the vector alone, as described previously. ${ }^{(42,43)}$ Stably transformed clones were selected, and the expression of RAGE variants were verified by Western blotting. The resultant clones were classified as HT1080 RAGE , HT1080 ${ }^{\text {dnRAGE }}$, and HT1080 mock cells. These cells were maintained in RPMI-1640 medium supplemented with $10 \%$ FBS, $100 \mathrm{U} / \mathrm{mL}$ penicillin and $100 \mu \mathrm{g} / \mathrm{mL}$ streptomycin in the presence of G418 (Geneticin, $750 \mu \mathrm{g} / \mathrm{mL}$; Roche Applied Science, Mannheim, Germany).

Nuclear factor- $\kappa$ B luciferase assay. Rat C6 glioma cells were used for this assay according to the previously described method. ${ }^{(38,39)}$ Briefly, cells were transfected with plasmid vectors encoding luciferase cDNA under the control of an enhan-

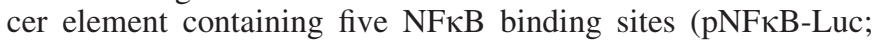
Stratagene Corp., La Jolla, CA, USA) and human full-length RAGE cDNA. Stably transfected clones were selected and used for the subsequent assay. After a 24-h preincubation in DMEM supplemented with $0.1 \%$ FBS, the cells were stimulated by $1.0 \mu \mathrm{g} / \mathrm{mL}$ HMGB1 (Sigma-Aldrich, St. Louis, MO, USA) with or without 0.1 and $1.0 \mathrm{IU} / \mathrm{mL} \mathrm{LMWH}$ (dalteparin sodium [Fragmin]; Pfizer Inc., New York, NY, USA) for $4 \mathrm{~h}$. The luciferase activity was determined using the Luciferase Assay System (Promega Corp., Madison, WI, USA) and measured in a luminometer (Fluoroscan Ascent FL; Labsystems, Helsinki, Finland).

Measurement of NFkB/p65, Rac1, and Cdc42 activities. To detect p65 nuclear translocation, NFкB/p65 ActiveELISA (Imgenex, San Diego, CA, USA) was used according to the manufacturer's protocol. The G-LISA Rac1 and Cdc42 Activation Assay Biochem kits (Cytoskeleton, Denver, CO, USA) were used for the measurement of Rac1 and $\mathrm{Cdc} 42$ activities, respectively.

Western blot analysis. Western blot analysis was carried out as previously described. ${ }^{(43)}$ Briefly, proteins $(40 \mu \mathrm{g})$ in the cell lysates were boiled and resolved by SDS-PAGE (12.5\%) then transferred onto a PVDF membrane (Millipore Corp., Bedford, MA, USA). The membranes were incubated with a polyclonal anti-RAGE antibody and IRDye 680 anti-rabbit IgG, and immunoreacted bands were visualized using the Odyssey Infrared Imaging system (LI-COR Biotechnology, Lincoln, NE, USA).

Flow cytometry. The expression of RAGE on the cell surface of transformed HT1080 human fibrosarcoma cells was confirmed by flow cytometry. Cells were stained with antihuman RAGE antibody (R\&D Systems, Minneapolis, MN, USA) and with anti-mouse IgG-Alexa Fluor 488 (Molecular Probes Inc., Eugene, OR, USA) $\left(15 \mathrm{~min}\right.$ at $4{ }^{\circ} \mathrm{C}$ in the dark) then resuspended in $200 \mu \mathrm{L}$ staining buffer containing $0.2 \mu \mathrm{g}$ $/ \mathrm{mL}$ propidium iodide (Sigma-Aldrich), filtered through a 100 $\mu \mathrm{m}$ mesh, and analyzed with FACS AriaII (BD Biosciences, San Jose, CA, USA). Data were transferred and reanalyzed with FlowJo software (Tree Star, San Carlos, CA, USA).

Confocal microscopy. The expression patterns of RAGE and HMGB1 in HT1080 were assessed under immunofluorescence confocal microscopy. HT1080 cells were cultured on Lab-Tek chamber slides (Nalge Nunc International, Naperville, IL, USA), fixed with PBS containing 4\% paraformaldehyde for $10 \mathrm{~min}$ and made permeable by incubating them with PBS containing $0.2 \%$ Triton $\mathrm{X}-100$ for $5 \mathrm{~min}$. After blocking with PBS containing $2 \% \mathrm{BSA}$ for $30 \mathrm{~min}$, cells were exposed to goat polyclonal antibody against the $\mathrm{V}$ domain of RAGE (1:800 dilution; Millipore) or against HMGB1 (1:50 dilution; Santa Cruz Biotechnology, Santa Cruz, CA, USA). ${ }^{(44)}$ Donkey anti-goat IgG labeled with Alexa Fluor 556 (1:200 dilution;
Molecular Probes) was used as the secondary antibody for the detection of RAGE or HMGB1; DAPI (Vectashield; Vector Laboratories Inc., Burlingame, CA, USA) was used for nuclear staining. The images were obtained with a fluorescence microscope (BZ-9000; Keyence, Osaka, Japan).

High mobility group box 1 ELISA. The HMGB1 levels in cell culture media were measured with a Shino-Test ELISA system (Tokyo, Japan). ${ }^{(8)}$

Cell proliferation assay. The HT1080 RAGE HT1080 $0^{\text {dnRAGE }}$ and HT1080 ${ }^{\text {mock }}$ cells were seeded at a density of $1 \times 10^{4}$ cells/well in a six-well plate (BD Biosciences). After incubation for $12 \mathrm{~h}$, culture medium was replaced with fresh RPMI1640 medium supplemented with $10 \%$ FBS with or without $1.0 \mu \mathrm{g} / \mathrm{mL}$ HMGB1 and/or $1 \mathrm{IU} / \mathrm{mL}$ LMWH. After additional incubation for $24 \mathrm{~h}$, cell proliferation was assessed by the MTT method, ${ }^{(45)}$ and the total viable cell number was counted on a hemocytometer using the dye exclusion method with $0.2 \%$ Trypan blue (Invitrogen, Carlsbad, CA, USA) at 0, 12, 24, 48, and $72 \mathrm{~h}$.

Cell migration assay. Cell migration was evaluated by a monolayer denudation assay as described previously. ${ }^{(46)}$ Briefly, HT1080 RAGE , HT1080 ${ }^{\mathrm{dnRAGE}}$, and HT1080 ${ }^{\text {mock }}$ cells were seeded at a density of $2 \times 10^{5}$ cells/well and were grown to confluence in a 6-well plate. Cells were then wounded by denuding a strip of the monolayer approximately $1 \mathrm{~mm}$ in width with a $200 \mu \mathrm{L}$ pipette tip. Cells were washed twice with serum-free RPMI-1640 medium then further incubated in RPMI-1640/10\% FBS with or without $1.0 \mu \mathrm{g} / \mathrm{mL}$ HMGB 1 and/or $1 \mathrm{IU} / \mathrm{mL}$ LMWH. The rate of wound closure was assessed in six separate fields after $24 \mathrm{~h}$ of the denudation using Image J software (http://rsb.info.nih.gov/ij/index.html).

Cell invasion assay. Matrigel-coated porous filters $(8-\mu \mathrm{m}$ pore size) in a 12-well format were used as a barrier in a Boyden chamber ${ }^{(39)}$ to assess the extent of the invasion by HT1080 RAGE, HT1080 dnRAGE, and HT1080 mock cells. Cells were plated into the inner chamber at an initial density of $2 \times 10^{5}$ with RPMI-1640/0.1\% BSA. The outer chamber was supplied with an addition of fibronectin $(500 \mu \mathrm{g} / \mathrm{mL})$. After $24 \mathrm{~h}$ incubation in the presence or absence of HMGB 1 $(1.0 \mu \mathrm{g} / \mathrm{mL})$ and/or LMWH $(1 \mathrm{IU} / \mathrm{mL})$ into both the inner and outer chambers, membranes were cut and removed from their insert housings. The filter membrane was fixed in $4 \%$ paraformaldehyde after the removal of non-invasive cells from the upper chamber using a cotton swab. The bottom surface containing the invasive cells was stained with crystal violet, and the invasive cells were counted in six separate fields using an optimal microscope at $\times 100$ magnification.

In vivo tumorigenesis and metastasis assays. Six-week-old female athymic nude mice (BALB/c-nu/nu; Japan SLC Co., Shizuoka, Japan) were used for the tumorigenesis and metastasis assays. HT1080 RAGE , HT1080 dnRAGE, and HT1080 ${ }^{\text {mock }}$ cells (each at $1 \times 10^{6}$ cells) were implanted s.c. into the back of the mice. For the LMWH treatment group, 80 IU LMWH was injected s.c. daily $24 \mathrm{~h}$ after the tumor cell implantation. The tumor size of the xenografts was measured weekly with calipers, and the tumor volume was estimated with the formula $\left(\right.$ width $\times$ length $\left.^{2}\right) / 2$ until 28 days after the implantation. For the metastasis assay, HT1080 RAGE, HT1080 ${ }^{\text {dnRAGE }}$, and HT1080 ${ }^{\text {mock }}$ cells $\left(1 \times 10^{6}\right.$ cells in 0.2 mL PBS $)$ were injected into the tail vein. For the LMWH treatment group, 80 IU LMWH were also injected s.c. daily. Twenty-eight days after the tumor cell injection, mice were killed and the lungs were resected. The colony number of metastatic tumor in the bilateral lung was counted. Animals were treated in accordance with the Fundamental Guidelines for the Proper Conduct of Animal Experiments and Related Activities in Academic Research Institutions under the jurisdiction of the Ministry of Education, Culture, Sports, Science and Technology of Japan. 


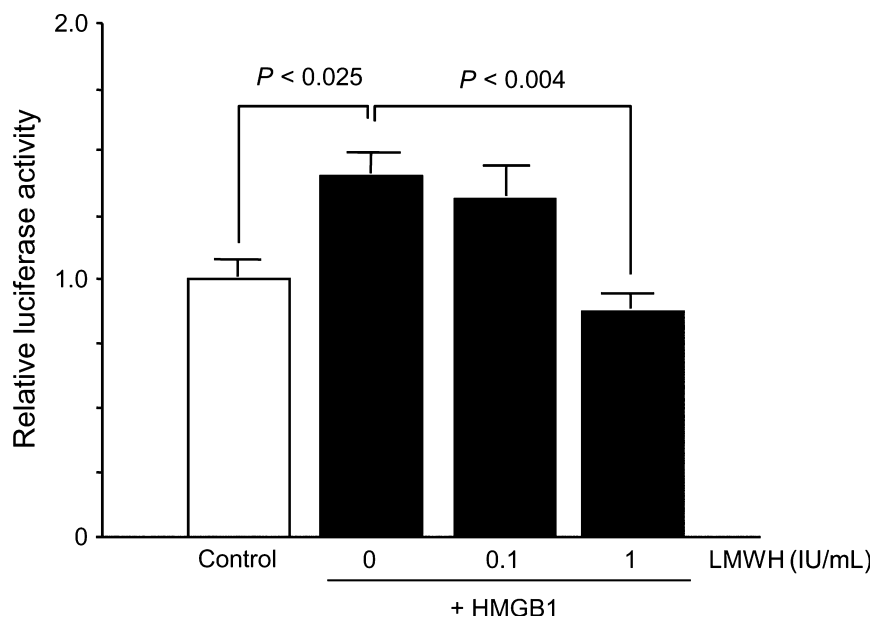

Fig. 1. Luciferase assay for nuclear factor $\kappa B$ activation. Cells were stimulated by $1.0 \mu \mathrm{g} / \mathrm{mL}$ high mobility group box 1 (HMGB1) with or without 0.1 and $1.0 \mathrm{IU} / \mathrm{mL}$ low molecular weight heparin (LMWH; dalteparin sodium) for $4 \mathrm{~h}$. The luciferase activity was measured. Values represent the mean $\pm \mathrm{SE}(n=4)$.

Animal experiments were approved by the Committee on Animal Experimentation of Kanazawa University (Kanazawa, Japan).

Statistical analyses. Analyses were carried out using Stat View (version 5.0; SAS Institute, Cary, NC, USA). One-way ANOVA and Fischer's exact tests were used when mean differences were identified between the groups. For all comparisons, values of $P<0.05$ were defined as significant.

\section{Results}

Low molecular weight heparin inhibition of HMGB1-RAGEinduced NFKB activation. We first examined whether LMWH could block HMGB1-induced NFKB activation in a C6 glioma cell line. The stable cell line expressing RAGE protein was previously established and useful for assaying RAGE-dependent NFKB activity. ${ }^{(41)}$ The addition of HMGB 1 at a concentration of $1 \mu \mathrm{g} / \mathrm{mL}$ significantly increased the NFKB promoter-driven luciferase activity when compared to the non-treated control (Fig. 1). The increased NFкB activation by HMGB1 was significantly attenuated by treatment with $1.0 \mathrm{IU} / \mathrm{mL}$ LMWH (Fig. 1). This is consistent with the antagonistic effect of LMWH on the AGE-RAGE axis, shown in our previous report. ${ }^{(41)}$

Effects of LMWH on cell proliferation, migration, and invasion in vitro. To investigate RAGE-dependency of the malignant phenotypes, we next generated three different types of transformed HT1080 human fibrosarcoma cells, HT1080RAGE, HT1080 dnRAGE, and HT1080 $0^{\text {mock }}$ cells. The expression of RAGE or dnRAGE was checked by Western blotting (Fig. 2a), and cell surface RAGE expression was evaluated by flow cytometry (Fig. 2b). There were markedly high expression levels of RAGE immunoreactivity in HT1080 RAGE and
HT1080 ${ }^{\text {dnRAGE }}$ cells; HT1080 ${ }^{\text {mock }}$ cells displayed a very low expression level of endogenous RAGE proteins (Fig. 2a,b). Immunofluorescent microscopy analysis revealed a nuclear staining of HMGB1 and a faint and diffuse cytoplasmic staining of RAGE expression in HT1080 mock cells (Fig. 2c). Secreted HMGB1 levels were not different among the three groups (Fig. 2d). To confirm the effects of LMWH on HMGB1-induced and RAGE-dependent cellular signaling such as NFkB, Rac1, and Cdc42, we cultured the three HT1080 cell lines under serum-deprived conditions. Obtained data clearly shows that HMGB1 could significantly induced NFkB, Rac1 and Cdc42 activities only in HT1080 ${ }^{\text {RAGE }}$ cells and the inductions were completely canceled by the treatment of LMWH (Fig. 2e-g). We then compared the malignant phenotypes of these cells in vitro. Cell proliferation of HT1080 RAGE cells was significantly higher than that of HT1080 ${ }^{\text {mock }}$ cells at every time point (Fig. 3a). In contrast, the cell number of HT1080 dnRAGE was significantly lower than that of HT1080 ${ }^{\text {mock }}$ cells (Fig. 3a). Although it was hard to see a stimulation of cell proliferation by the addition of HMGB1 under RPMI-1640 media with 10\% FBS, cell counting and MTT assays also revealed the highest rate of cell proliferation in $\mathrm{HT} 1080^{\mathrm{RAGE}}$ cells (Fig. 3b,c). We speculated that HMGB1 in the complete culture media sufficiently stimulated the cell proliferation in an autocrine and a paracrine fashion, as an addition of neutralizing antibody against HMGB1 was found to significantly inhibit the cell proliferation (data not shown). In the cell migration assay, the rate of wound closure was significantly higher in HT1080 RAGE cells than HT1080 mock or HT1080 dnRAGE cells at $24 \mathrm{~h}$ after a monolayer denudation (Fig. 4). The Boyden chamber cell invasion assay revealed that HT1080 RAGE cells had the highest number of invasive cells among the groups; the invasive cell number of HT1080 dnRAGE cells was significantly lower than that of HT1080 ${ }^{\text {mock }}$ cells (Fig. 5). Overexpression of RAGE thus exacerbated, but overexpression of dnRAGE attenuated, the malignancy-related cellular phenotype in HT1080 fibrosarcoma cells.

The effects of LMWH on the RAGE-mediated cell proliferation, migration, and invasion of HT1080 cells were then examined. The LMWH significantly inhibited cell proliferation and migration in HT1080 RAGE cells, but not in HT1080 ${ }^{\text {mock }}$ or HT1080 dnRAGE cells (Fig. 3b,c, Fig. 4). The treatment with LMWH also significantly blocked the RAGE-overexpressioninduced cell invasion in HT1080 RAGE cells, but not in HT1080 $0^{\text {mock }}$ or HT1080 ${ }^{\text {dnRAGE }}$ cells (Fig. 5).

Effects of LMWH on tumorigenesis and metastasis in vivo. After obtaining positive results for LMWH in vitro, we then examined the in vivo effects of LMWH on tumorigenesis and metastasis using nude mice. After 28 days of tumor cell implantation in the back, the mean tumor volume of HT1080RAGE cells was significantly larger than that of HT1080 ${ }^{\text {mock }}$ cells (Fig. 6a). With HT1080 ${ }^{\mathrm{dnRAGE}}$ cells, there was a tendency of suppression of the increase in the tumor volume (Fig. 6a). Treatment with LMWH apparently inhibited the local tumor growth of HT1080 RAGE cells compared to PBS-treated controls during the observation period of 4 weeks (Fig. 6b). However, LMWH did not show any inhibitory effects on the local tumor growth in either HT1080 mock

Fig. 2. (Figure on next page) Expression of receptor for advanced glycation end products (RAGE) and high mobility group box 1 (HMGB1) and HMGB1-mediated RAGE signaling. (a) RAGE expression was examined by Western blotting. (b) Cell surface RAGE was examined by flow cytometry. (c) Expression patterns of RAGE and HMGB1 in mock-transfected control (HT1080 mock) cells were determined by immunofluorescence confocal microscopy (a,b, Alexa Fluor 556; c,d, DAPI). Magnification, $\times 40$. Scale bar $=50 \mu \mathrm{m}$. (d) HMGB1 levels in cell culture media. Each cell was cultured in serum-free media for $24 \mathrm{~h}$ and the HMGB1 concentration was then assayed with ELISA. (e-g) Nuclear factor-kB/p65, Rac1, and Cdc42 activities. Each cell was cultured in $0.1 \%$ serum media. $\mathrm{C}$, non-treated control; $\mathrm{H}, 0.1 \mu \mathrm{g} / \mathrm{mL} \mathrm{HMGB} 1 ; \mathrm{H}+\mathrm{L}, 0.1 \mu \mathrm{g} / \mathrm{mL} \mathrm{HMGB} 1$ and $1.0 \mathrm{IU} / \mathrm{mL}$ LMWH; HT1080 dnRAGE, RAGE dominant-negative, intracellular tail-deleted RAGE-overexpressing fibrosarcoma cells; HT1080 RAGE, human full-length RAGE-overexpressing fibrosarcoma cells. Values represent the mean $\pm \operatorname{SE}(n=3)$. 
(a)

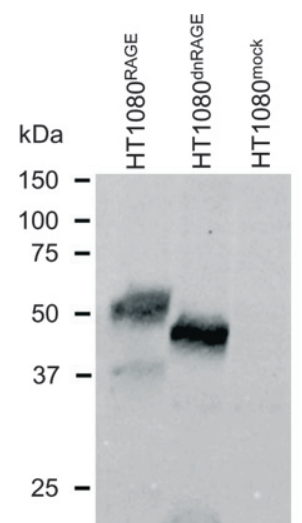

(c)
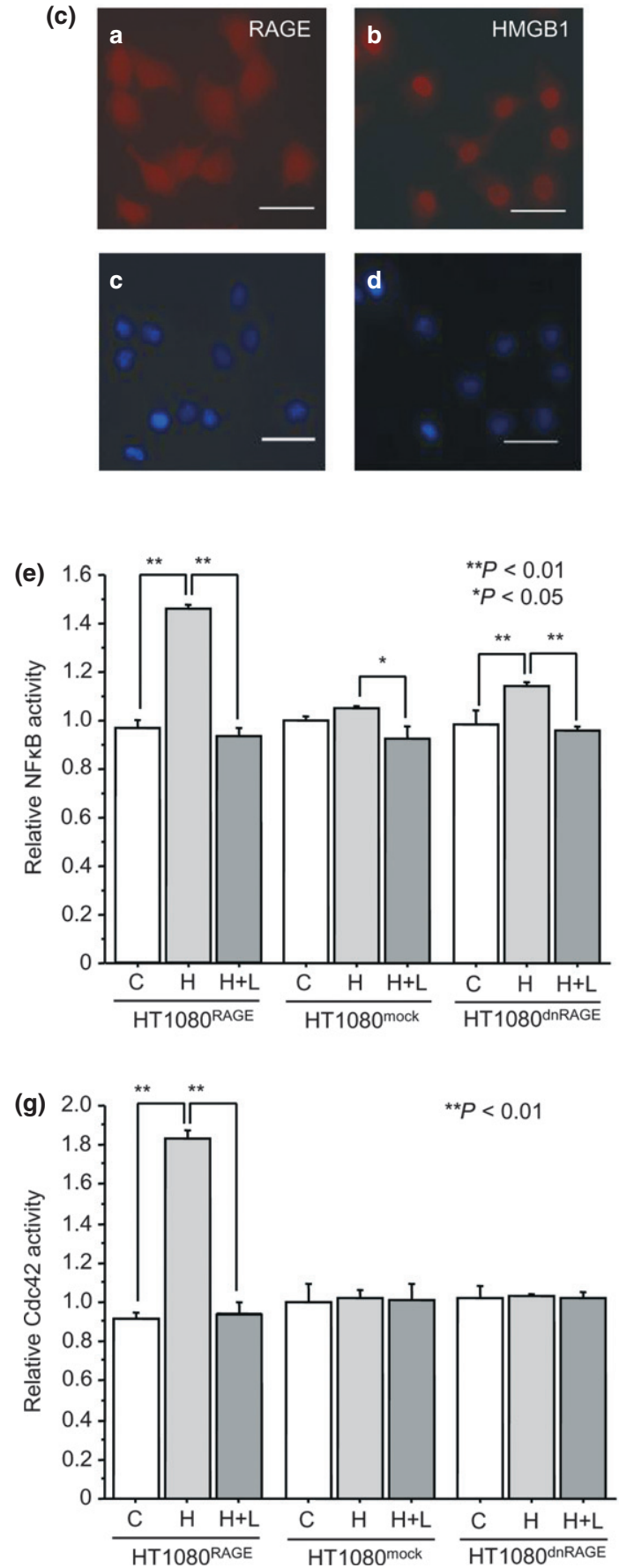
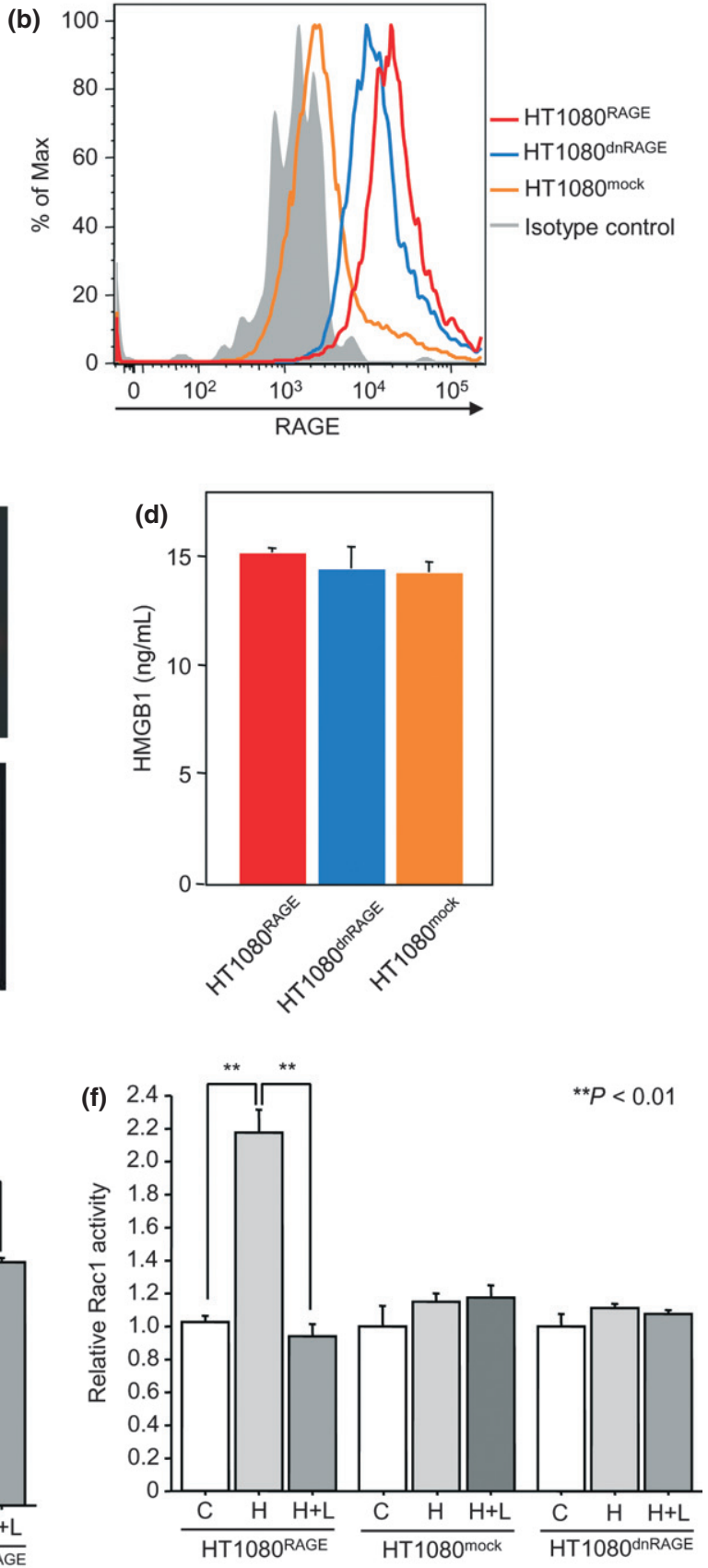
or HT1080 ${ }^{\text {dnRAGE }}$ cells (Fig. 6c,d). We then assessed tumor cell metastasis to the lung. The number of tumor colonies in the lung significantly increased in the HT1080 RAGE cells compared to HT1080 ${ }^{\text {mock }}$ cells after 28 days of tail vein injection of the cells (Fig. 6e). The number was found to be the lowest in the HT1080 dnRAGE cells (Fig. 6f). Moreover, the treatment of LMWH significantly suppressed the lung metastasis of HT1080 RAGE cells when compared to the PBS-treated control group (Fig. 6f). During the experimental periods, we could not find any obvious side-effects of LMWH on nude mice.

\section{Discussion}

The interaction between HMGB1 and RAGE has been reported to contribute to tumor cell proliferation and invasiveness. $(10,18)$ Clinicohistopathogical studies showed the expression of RAGE was associated with prognosis in various types of malignant (a)

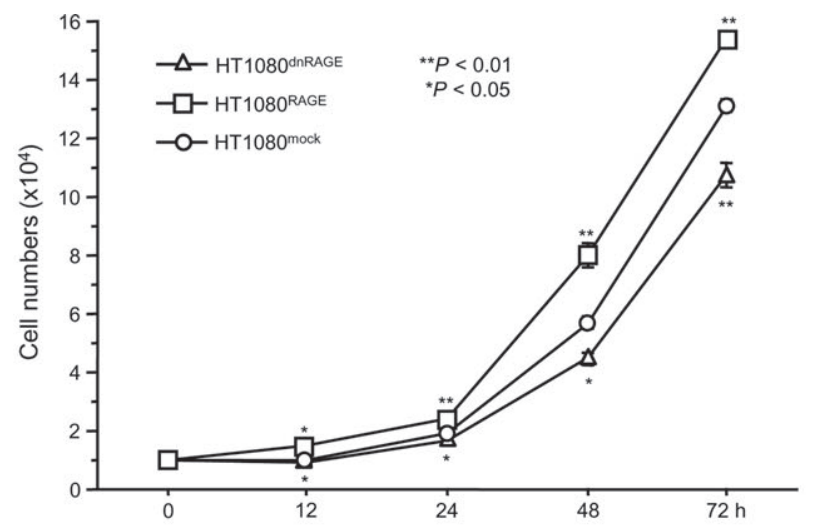

(b)

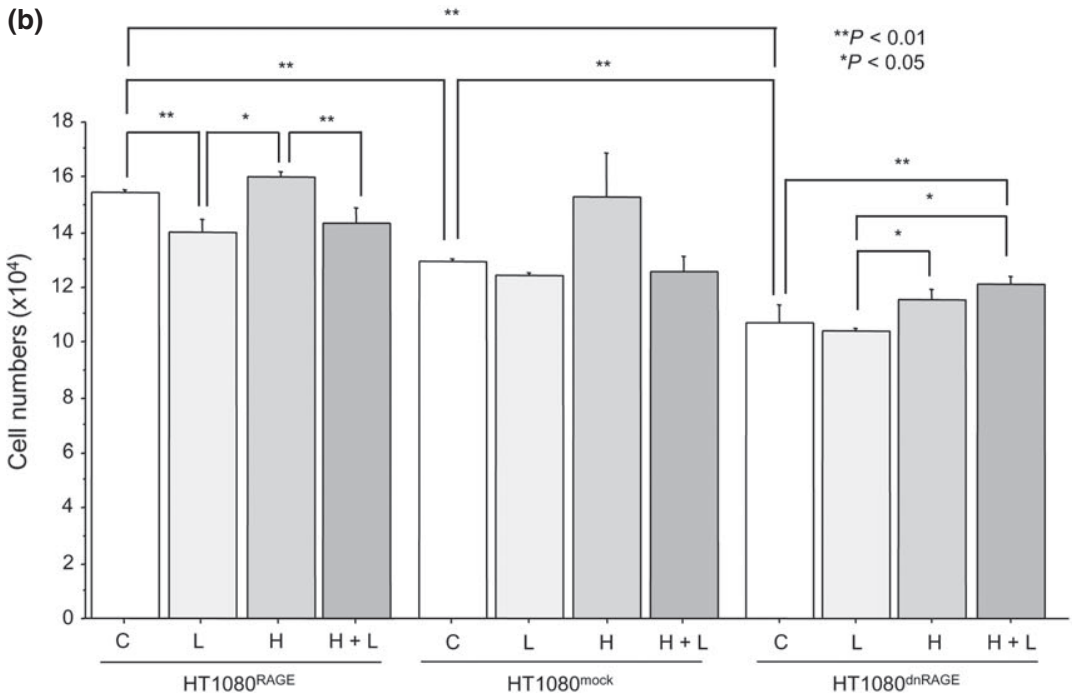

(c)

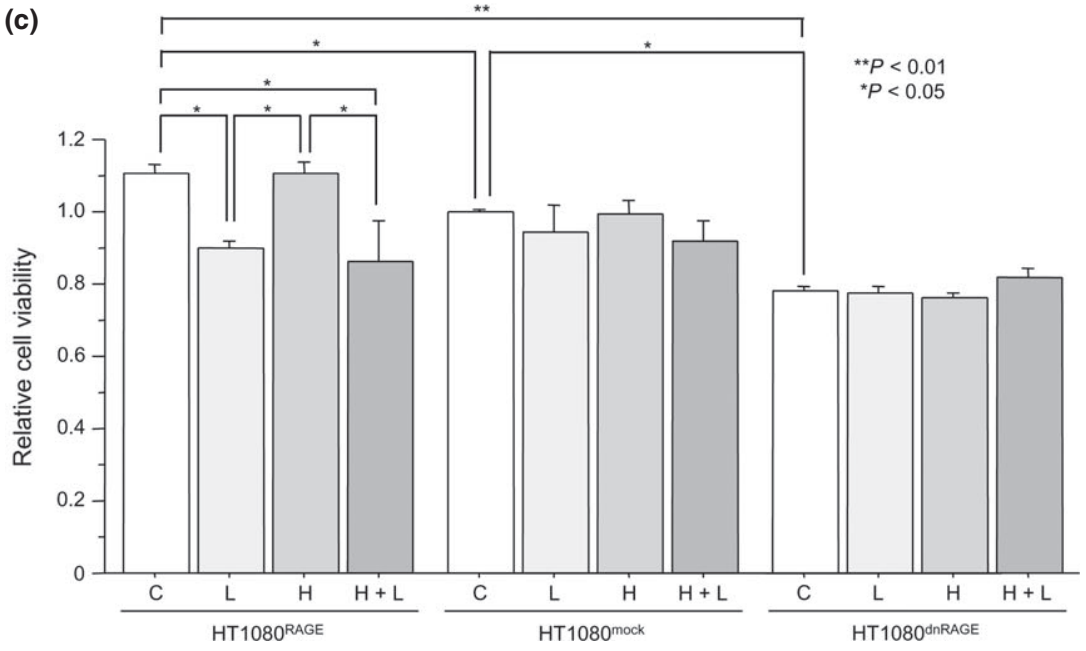

Fig. 3. Cell proliferation. (a) Viable cell number was calculated at $0,12,24,48$, and $72 \mathrm{~h}$ after the seeding of human full-length receptor for advanced glycation end products (RAGE)-overexpressing (HT1080 RAGE), RAGE dominant-negative, intracellular tail-deleted RAGE-overexpressing (HT1080 dnRAGE), and mocktransfected control (HT1080 ${ }^{\text {mock}}$ ) fibrosarcoma cells. Values represent the mean $\pm \operatorname{SE}(n=5)$. (b) Viable cell number was calculated at $72 \mathrm{~h}$ after cell seeding and (c) MTT assay was carried out under $10 \%$ serum media. $\mathrm{C}$, non-treated control; $\mathrm{H}, 0.1 \mu \mathrm{g} / \mathrm{mL}$ high mobility group box 1 (HMGB1); $\mathrm{H}+\mathrm{L}, 0.1 \mu \mathrm{g} / \mathrm{mL}$ HMGB1 and $1.0 \mathrm{IU} / \mathrm{mL}$ low molecular weight heparin. Values represent the mean $\pm \mathrm{SE}(n=5)$. 
(a)
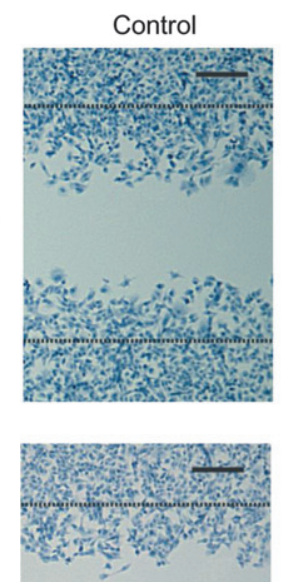

HT1080 mock
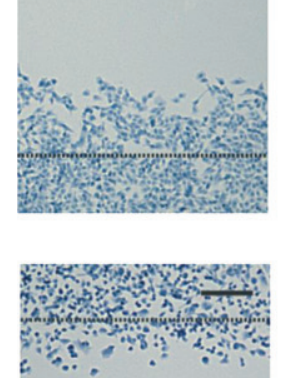

HT1080dnRAGE

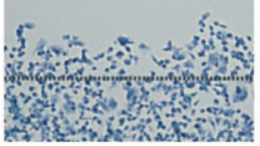

LMWH
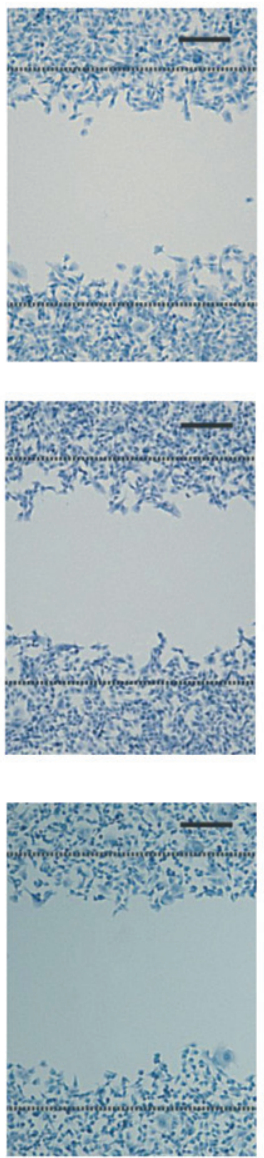

HMGB1
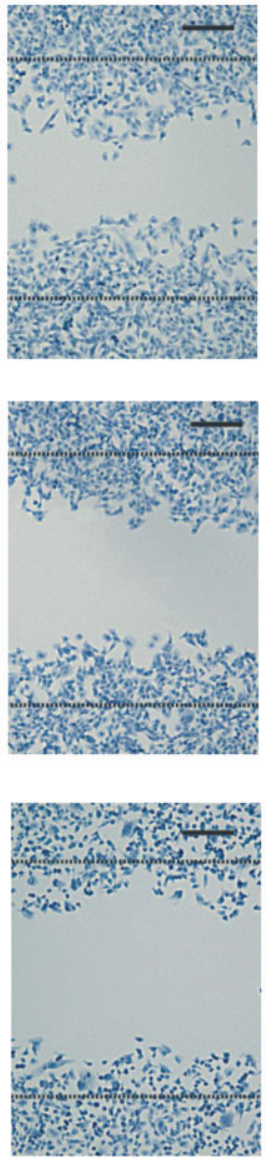

HMGB1+LMWH
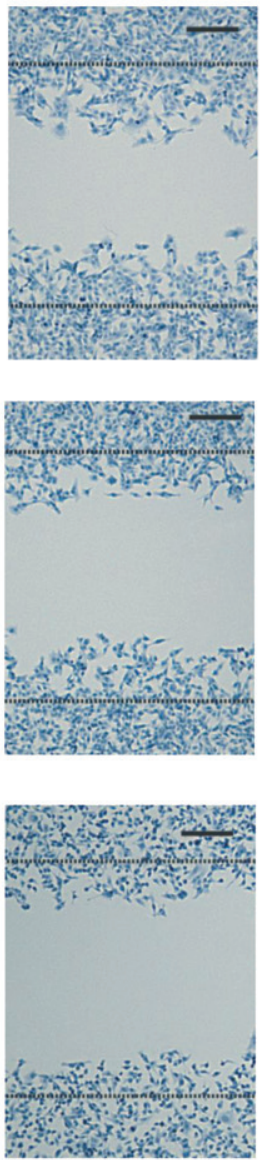

(b)

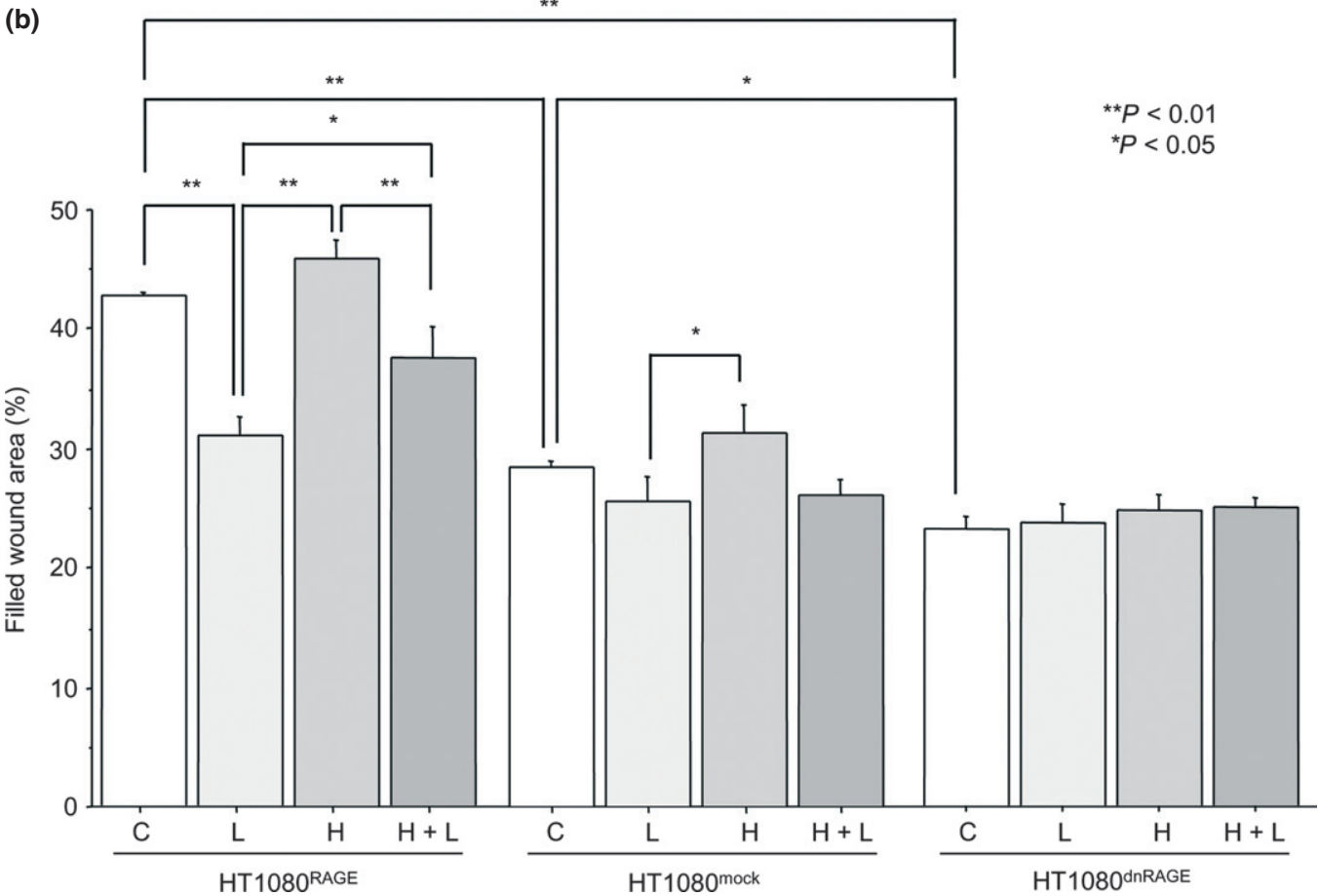

Fig. 4. Cell migration. Scratch wound assay was carried out using human full-length receptor for advanced glycation end products (RAGE)-overexpressing (HT1080 RAGE), RAGE dominant-negative, intracellular tail-deleted RAGE-overexpressing (HT1080 ${ }^{\text {dnRAGE}}$, and mock-transfected control (HT1080 ${ }^{\text {mock }}$ ) fibrosarcoma cells under $10 \%$ serum media. The rectangle composed of black lines indicates the area of the initial scratch wound. The filled wound area was calculated. Scale bar $=200 \mu \mathrm{m}$. C, non-treated control; $\mathrm{H}, 0.1 \mu \mathrm{g} / \mathrm{mL}$ high mobility group box $1(\mathrm{HMGB} 1) ; \mathrm{H}+\mathrm{L}, 0.1 \mu \mathrm{g} / \mathrm{mL} \mathrm{HMGB} 1 \mathrm{and}$ $1.0 \mathrm{IU} / \mathrm{mL}$ low molecular weight heparin. Values represent the mean $\pm \mathrm{SE}(n=5)$. 
(a)
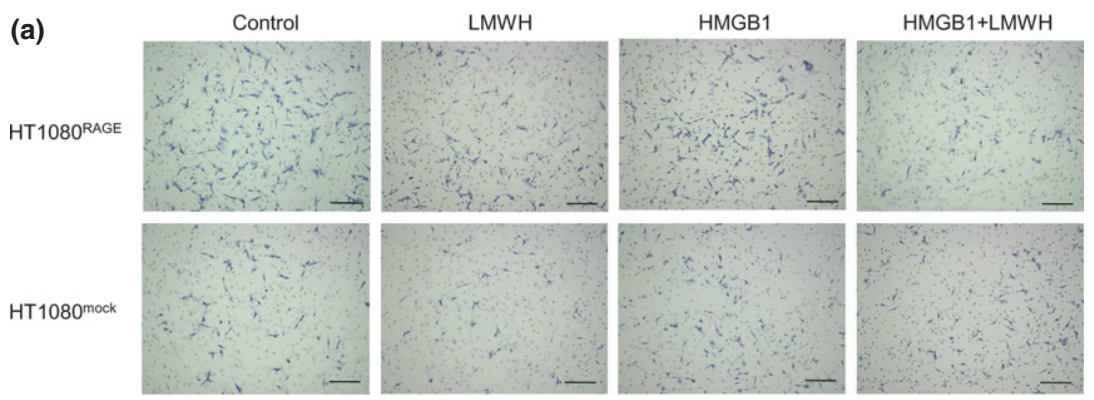

HT1080 dnRAGE
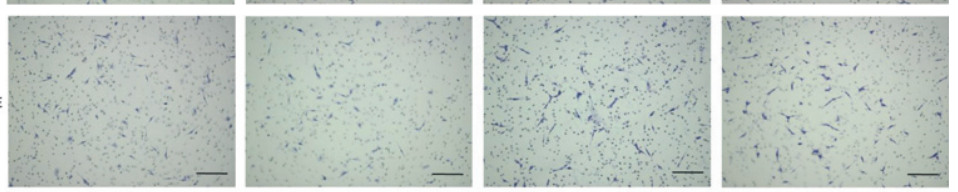

(b)

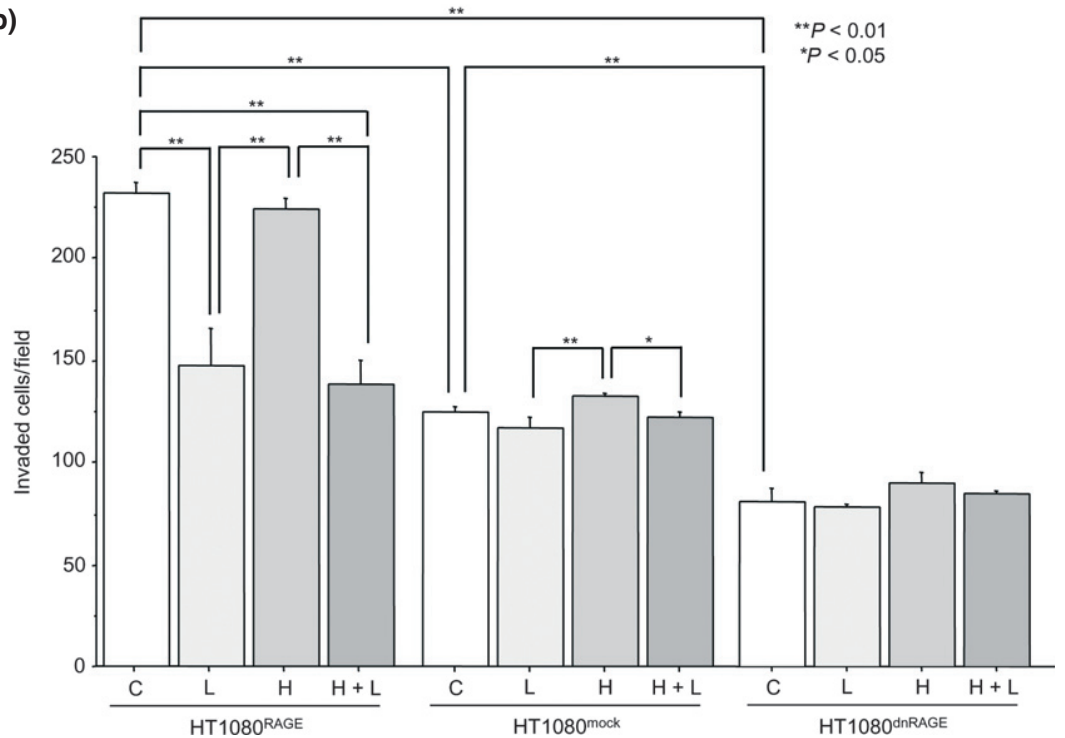

Fig. 5. Cell invasion. Matrigel cell invasion assay was carried out using human full-length receptor for advanced glycation end products (RAGE)-overexpressing $($ HT1080 RAGE), RAGE dominant-negative, intracellular tail-deleted RAGE-overexpressing (HT1080 $0^{\text {dnRAGE}}$ ), and mock-transfected control (HT1080 ${ }^{\text {mock}) ~ f i b r o s a r c o m a ~}$ cells under $10 \%$ serum media. Scale bar $=200 \mu \mathrm{m}$. $C$, non-treated control; $\mathrm{H}, 0.1 \mu \mathrm{g} / \mathrm{mL}$ high mobility group box 1 (HMGB1); $\mathrm{H}+\mathrm{L}, 0.1 \mu \mathrm{g} / \mathrm{mL}$ HMGB1 and $1.0 \mathrm{IU} / \mathrm{mL}$ low molecular weight heparin. Values represent the mean $\pm \operatorname{SE}(n=5)$. tumors, such as lung, ${ }^{(20)}$ breast, ${ }^{(20)}$ and prostate cancers, ${ }^{(21,22)}$ as well as malignant melanoma. ${ }^{(20)}$ The present study clearly indicated that the overexpression of human full-length signaltransducing RAGE in HT1080 cells aggravated the cellular phenotype in terms of proliferation, migration, and invasion in vitro, and tumorigenesis and distant metastasis in vivo (Figs 3-6). In contrast, forced expression of intracellular domain-deleted dominant-negative RAGE significantly inhibited cell proliferation, invasion, and metastasis (Figs 3-6). These results indicate that RAGE is a key regulator of the malignant phenotype in tumor cells, which is in agreement with previous findings using N18 neuroblastoma, B16-F1 melanoma, and C6 glioma cells. ${ }^{(11,18)}$ Therefore, RAGE is a promising therapeutic target in tumor malignancy. For targeting RAGE, Huttunen et al. used a C-terminal motif in the form of an amphoterin/HMGB1 peptide (amino acids 150-183), which was shown to bind to RAGE and efficiently inhibit the invasive migration of HT1080 cells. ${ }^{(18)}$ Taguchi et al. reported that the blockade of HMGB1-RAGE using soluble RAGE decreased C6 glioma cell tumor growth and metastasis. ${ }^{(11)}$ Our group showed that the LMWH dalteparin had an antagonistic effect on RAGE and attenuated the development and progression of diabetic nephropathy. ${ }^{(41)}$ Subsequent to our previous report, it was reported that 2-O,3-O-desulfated heparin, another low molecular weight anticoagulant heparin derivative produced from cold alkaline hydrolysis of unfractionated heparin, had a similar antagonistic action against RAGE. ${ }^{(47)}$ Accordingly, we decided to use dalteparin for tumor treatment and to investigate whether LMWH has an antitumor effect through a blockade of RAGE within the therapeutic range of the plasma LMWH concentrations.

The correlation between cancer and thrombosis is well documented. ${ }^{(28-34)}$ Heparins represent the first choice for the prevention and treatment of venous thromboembolism. In particular, LMWH possesses certain pharmacokinetic advantages over unfractionated heparin, including a longer half-life, better bioavailability, and lower binding to plasma proteins. The results of preclinical and clinical studies have suggested that LMWH might inhibit cell growth, cell invasion, and angiogenesis in cancer, indicating its anticoagulant and direct antitumor effects. ${ }^{(35-38)}$ Moreover, several clinical trials have shown an improvement in overall survival by LMWH treatment in cancer patients, even in those at advanced stage of disease. ${ }^{(36-39)}$ The efficacy of LMWH treatment has been reported in various histological types of malignancies including lung, ${ }^{(39)}$ breast, ${ }^{(37)}$ gastric, ${ }^{(37)}$ hepatic, ${ }^{(37)}$ colorectal, ${ }^{(37)}$ pancreatic, ${ }^{(48)}$ and prostatic cancers. ${ }^{(37)}$

In this study, we report for the first time that LMWH significantly inhibits the cell proliferation, migration, invasion, local tumor growth, and lung metastasis of HT1080 fibrosarcoma cells through a blockade of the RAGE axis (Figs 3-6). The in vitro and in vivo data for the most part clearly indicate that the antagonistic effect of LMWH against RAGE inhibit tumor cell growth, migration, invasion, and distant metastasis (Figs 3-6). Concerning a possible additional direct antitumor effect of LMWH, Harvey et al. suggested an 

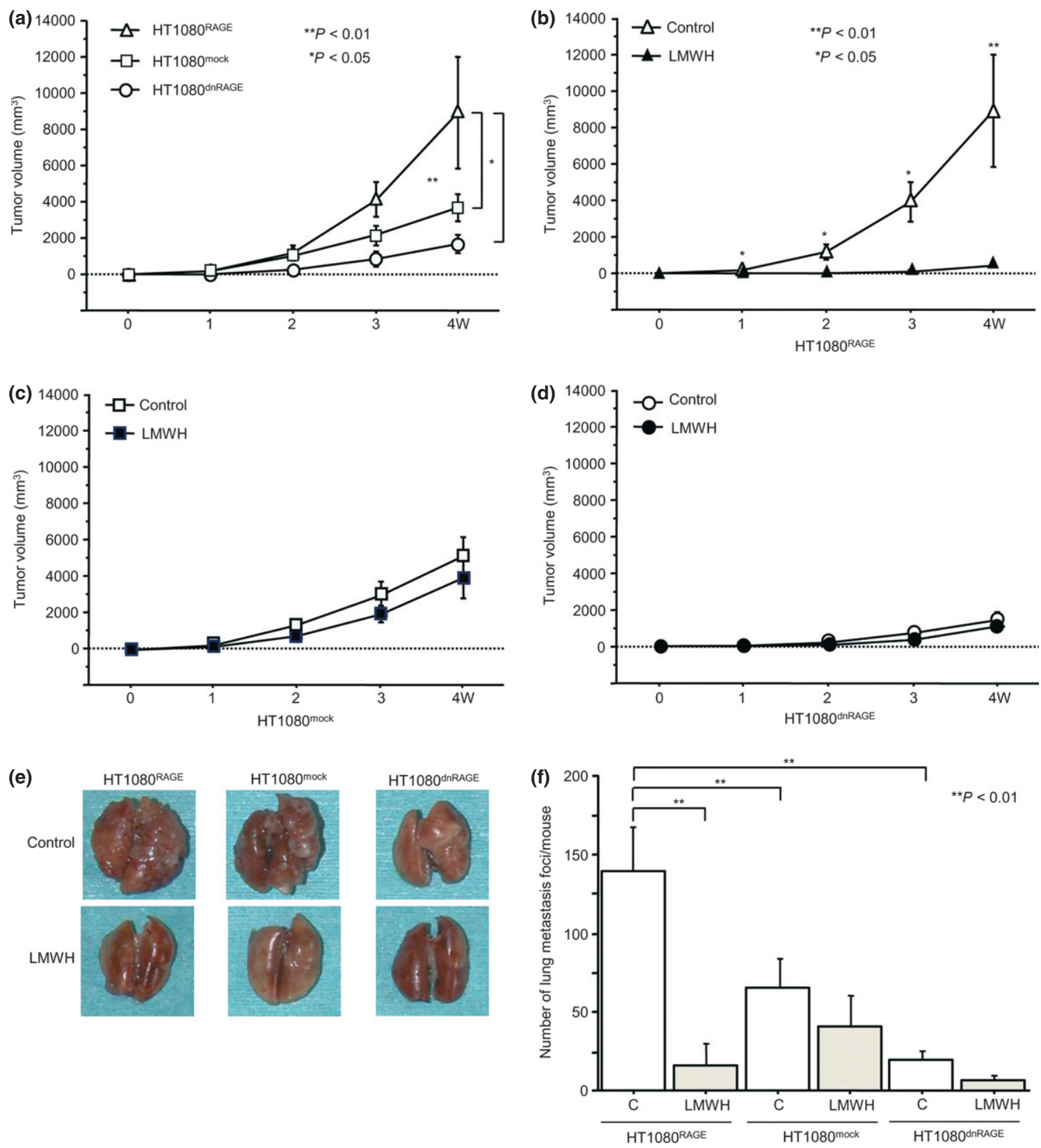

Fig. 6. In vivo tumorigenesis assay. (a) Human full-length receptor for advanced glycation end products (RAGE)-overexpressing (HT1080RAGE) RAGE dominant-negative, intracellular tail-deleted RAGE-overexpressing (HT1080 ${ }^{\text {dnRAGE}}$ ), and mock-transfected control (HT1080 ${ }^{\text {mock }}$ ) fibrosarcoma cells were implanted into the back of athymic nude mice (BALB/c-nu/nu) at a density of $1 \times 10^{6}$ cells. The local tumor volume was calculated at $0,1,2,3$, and 4 weeks after the implantation. Values represent the mean \pm SE $(n=5)$. (b) Low molecular weight heparin (LMWH) treatment significantly blocked the local tumor growth of HT1080RAGE cells. Control, mice receiving a daily injection of PBS; LMWH, mice receiving a daily injection of $80 \mathrm{IU} \mathrm{LMWH}$. Values represent the mean $\pm \mathrm{SE}(n=5)$. Treatment with LMWH did not affect the local tumor growth of HT1080 ${ }^{\text {mock }}$ cells (c) or HT1080 dnRAGE cells (d). Control, PBS injection; LMWH, LMWH injection. Values represent the mean \pm SE $(n=5)$. In vivo lung metastasis

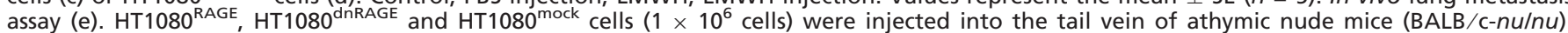
The number of lung colonies was assessed (f). C, control mice receiving daily injection of PBS; LMWH, mice receiving daily injection of 80 IU $\mathrm{LMWH}$. Values represent the mean $\pm \mathrm{SE}(n=5)$.

antagonistic effect of LMWH on CXCR4 in breast cancer cell metastasis. ${ }^{(40)}$ The heterocomplex between HMGB1 and CXCL12 was reported to be involved in mononuclear cell recruitment through $\mathrm{CXCR} 4,{ }^{(49)}$ and $\mathrm{Ma}$ et al. also reported that LMWH inhibited the formation of hepatic metastasis of colon cancer cells by disrupting the interaction of CXCR4 and CXCL12. ${ }^{(50)}$ Although LMWH is a multifunctional biological molecule, and other yet unknown functions of LMWH may be discovered, LMWH is already suggested to be a useful drug for tumor therapy, especially as a novel adjuvant cancer treatment. To assess the efficacy of LMWH for the treatment of bone and soft tissue sarcoma, the expression of RAGE should be assessed. We found a potent expression of RAGE in certain types of sarcomas (data not shown). Large prospective cohort studies will be required to draw a conclusion about the efficacy of LMWH and to evaluate the effect of clinical applications in patients with various cancers.

In conclusion, this study has shown that the LMWH dalteparin has an antagonistic effect against RAGE, thereby 
contributing to the inhibition of tumor cell growth, migration, invasion, and distant metastasis in human fibrosarcoma cells.

\section{Acknowledgments}

The authors thank Ms Yuko Niimura for her assistance. Pacific Edit reviewed the manuscript prior to submission. This study was supported by a Grant-in-Aid for Scientific Research (19390085) from the Japan Society for the Promotion of Sciences. The funders had no role in study design, data collection and analysis, decision to publish, or preparation of the manuscript.

\section{Disclosure Statement}

The authors have no conflicts of interest.

\section{References}

1 Schmidt AM, Yan SD, Yan SF et al. The multiligand receptor RAGE as a progression factor amplifying immune and inflammatory responses. J Clin Invest 2001; 108: 949-55.

2 Neeper M, Schmidt AM, Brett J et al. Cloning and expression of a cell-surface receptor for advanced glycosylation end-products of proteins. J Biol Chem 1992; 267: 14998-5004

3 Hofmann MA, Drury S, Fu C et al. RAGE mediates a novel proinflammatory axis: a central cell surface receptor for S100/calgranulin polypeptides. Cell 1999; 97: 889-901.

4 Moroz OV, Antson AA, Dodson EJ et al. The structure of S100A12 in a hexameric form and its proposed role in receptor signalling. Acta Crystallogr D Biol Crystallogr 2002; 58: 407-13.

5 Du Yan S, Zhu H, Fu J et al. Amyloid-beta peptide-receptor for advanced glycation endproduct interaction elicits neuronal expression of macrophagecolony stimulating factor: a proinflammatory pathway in Alzheimer disease. Proc Natl Acad Sci USA 1997; 94: 5296-301.

6 Yan SD, Chen X, Fu J et al. RAGE and amyloid-beta peptide neurotoxicity in Alzheimer's disease. Nature 1996; 382: 685-91.

7 Pullerits R, Brisslert M, Jonsson IM, Tarkowski A. Soluble receptor for advanced glycation end products triggers a proinflammatory cytokine cascade via beta2 integrin Mac-1. Arthritis Rheum 2006; 54: 3898-907.

8 Yamamoto Y, Harashima A, Saito H et al. Septic shock is associated with receptor for advanced glycation end products ligation of LPS. J Immunol 2011; 186: 3248-57.

$9 \mathrm{He}$ M, Kubo H, Morimoto $\mathrm{K}$ et al. Receptor for advanced glycation end products binds to phosphatidylserine and assists in the clearance of apoptotic cells. EMBO Rep 2011; 12: 358-64.

10 Chavakis T, Bierhaus A, Al-Fakhri $\mathrm{N}$ et al. The pattern recognition receptor (RAGE) is a counterreceptor for leukocyte integrins: a novel pathway for inflammatory cell recruitment. $J$ Exp Med 2003; 198: 1507-15.

11 Taguchi A, Blood DC, del Toro G et al. Blockade of RAGE-amphoterin signalling suppresses tumour growth and metastases. Nature 2000; 405: 354-60.

12 Hori O, Brett J, Slattery T et al. The receptor for advanced glycation end products (RAGE) is a cellular binding site for amphoterin. Mediation of neurite outgrowth and co-expression of rage and amphoterin in the developing nervous system. J Biol Chem 1995; 270: 25752-61.

13 Yamamoto Y, Ymamoto H. Receptor for advanced glycation end-productsmediated inflammation and diabetic vascular complications. J Diabetes Investig 2011; 2: 155-7.

14 Yamamoto Y, Kato I, Doi T et al. Development and prevention of advanced diabetic nephropathy in RAGE-overexpressing mice. $J$ Clin Invest 2001;108:261-8.

15 Yeh CH, Sturgis L, Haidacher J et al. Requirement for p38 and p44/p42 mitogen-activated protein kinases in RAGE-mediated nuclear factor-kappaB transcriptional activation and cytokine secretion. Diabetes 2001; 50: 1495504.

16 Sakaguchi M, Murata H, Yamamoto K et al. TIRAP, an adaptor protein for TLR2/4, transduces a signal from RAGE phosphorylated upon ligand binding. PLOS ONE 2011; 6: e23132.

17 Huttunen HJ, Fages C, Rauvala H. Receptor for advanced glycation end products (RAGE)-mediated neurite outgrowth and activation of NF-kappaB require the cytoplasmic domain of the receptor but different downstream signaling pathways. J Biol Chem 1999; 274: 19919-24.

18 Huttunen HJ, Fages C, Kuja-Panula J, Ridley AJ, Rauvala H. Receptor for advanced glycation end products-binding $\mathrm{COOH}$-terminal motif of amphoterin inhibits invasive migration and metastasis. Cancer Res 2002; 62: 4805 11 .

\section{Abbreviations}

HT1080 RAGE human full-length RAGE-overexpressing human fibrosarcoma cell line

HT1080 ${ }^{\text {dnRAGE }}$ RAGE dominant-negative, intracellular tail-deleted

RAGE-overexpressing human fibrosarcoma cell line

AGE $\quad$ mock-transfected control human

HMGB1 high mobility group box 1

LMWH low molecular weight heparin

$\mathrm{NF} \kappa \mathrm{B} \quad$ nuclear factor- $\kappa \mathrm{B}$

RAGE receptor for advanced glycation end products
19 Kuniyasu H, Oue N, Wakikawa A et al. Expression of receptors for advanced glycation end-products (RAGE) is closely associated with the invasive and metastatic activity of gastric cancer. J Pathol 2002; 196: 163-70.

20 Hsieh HL, Schafer BW, Sasaki N, Heizmann CW. Expression analysis of S100 proteins and RAGE in human tumors using tissue microarrays. Biochem Biophys Res Commun 2003; 307: 375-81.

21 Kuniyasu H, Chihara Y, Kondo H, Ohmori H, Ukai R. Amphoterin induction in prostatic stromal cells by androgen deprivation is associated with metastatic prostate cancer. Oncol Rep 2003; 10: 1863-8.

22 Takeuchi A, Yamamoto Y, Tsuneyama K et al. Endogenous secretory receptor for advanced glycation endproducts as a novel prognostic marker in chondrosarcoma. Cancer 2007; 109: 2532-40.

23 Eilber F, Giuliano A, Eckardt J, Patterson K, Moseley S, Goodnight J. Adjuvant chemotherapy for osteosarcoma: a randomized prospective trial. J Clin Oncol 1987; 5: 21-6.

24 Jurgens H, Exner U, Gadner $\mathrm{H}$ et al. Multidisciplinary treatment of primary Ewing's sarcoma of bone. A 6-year experience of a European Cooperative Trial. Cancer 1988; 61: 23-32.

25 Pisters PW, Patel SR, Varma DG et al. Preoperative chemotherapy for stage IIIB extremity soft tissue sarcoma: long-term results from a single institution. J Clin Oncol 1997; 15: 3481-7.

26 Meric F, Hess KR, Varma DG et al. Radiographic response to neoadjuvant chemotherapy is a predictor of local control and survival in soft tissue sarcomas. Cancer 2002; 95: 1120-6.

27 Eilber FC, Rosen G, Eckardt J et al. Treatment-induced pathologic necrosis: a predictor of local recurrence and survival in patients receiving neoadjuvant therapy for high-grade extremity soft tissue sarcomas. J Clin Oncol 2001; 19: 3203-9.

28 Goerner A. The influence of anticlotting agents on transplantation and growth of tumor tissue. J Lab Clin Med 1930; 16: 369-72.

29 Elias EG, Shukla SK, Mink IB. Heparin and chemotherapy in the management of inoperable lung carcinoma. Cancer 1975; 36: 129-36.

30 Halkin H, Goldberg J, Modan M et al. Reduction of mortality in general medical in-patients by low-dose heparin prophylaxis. Ann Intern Med 1982; 96: $561-5$.

31 Lebeau B, Chastang C, Brechot JM et al. Subcutaneous heparin treatment increases survival in small cell lung cancer. "Petites Cellules" Group. Cancer 1994; 74: 38-45.

32 Zacharski LR, Henderson WG, Rickles FR et al. Effect of warfarin anticoagulation on survival in carcinoma of the lung, colon, head and neck, and prostate. Final report of VA Cooperative Study \#75. Cancer 1984; 53: 2046-52.

33 Chahinian AP, Propert KJ, Ware JH et al. A randomized trial of anticoagulation with warfarin and of alternating chemotherapy in extensive small-cell lung cancer by the Cancer and Leukemia Group B. J Clin Oncol 1989; 7: 993-1002.

34 Marmur JD, Anand SX, Bagga RS et al. The activated clotting time can be used to monitor the low molecular weight heparin dalteparin after intravenous administration. J Am Coll Cardiol 2003; 41: 394-402.

35 Beeler D, Rosenberg R, Jordan R. Fractionation of low molecular weight heparin species and their interaction with antithrombin. J Biol Chem 1979; 254: 2902-13

36 Lazo-Langner A, Goss GD, Spaans JN, Rodger MA. The effect of lowmolecular-weight heparin on cancer survival. A systematic review and metaanalysis of randomized trials. J Thromb Haemost 2007; 5: 729-37.

37 von Tempelhoff GF, Harenberg J, Niemann F, Hommel G, Kirkpatrick CJ, Heilmann L. Effect of low molecular weight heparin (Certoparin) versus unfractionated heparin on cancer survival following breast and pelvic cancer surgery: a prospective randomized double-blind trial. Int J Oncol 2000; 16: 815-24. 
38 Nagy Z, Turcsik V, Blasko G. The effect of LMWH (Nadroparin) on tumor progression. Pathol Oncol Res 2009; 15: 689-92.

39 Altinbas M, Coskun HS, Er O et al. A randomized clinical trial of combination chemotherapy with and without low-molecular-weight heparin in small cell lung cancer. J Thromb Haemost 2004; 2: 1266-71.

40 Harvey JR, Mellor P, Eldaly H, Lennard TW, Kirby JA, Ali S. Inhibition of CXCR4-mediated breast cancer metastasis: a potential role for heparinoids? Clin Cancer Res 2007; 13: 1562-70.

41 Myint KM, Yamamoto Y, Doi T et al. RAGE control of diabetic nephropathy in a mouse model: effects of RAGE gene disruption and administration of low-molecular weight heparin. Diabetes 2006;55:2510-22.

42 Harashima A, Yamamoto Y, Cheng C et al. Identification of mouse orthologue of endogenous secretory receptor for advanced glycation end-products: structure, function and expression. Biochem J 2006; 396: 109-15.

43 Yonekura H, Yamamoto Y, Sakurai S et al. Novel splice variants of the receptor for advanced glycation end-products expressed in human vascular endothelial cells and pericytes, and their putative roles in diabetes-induced vascular injury. Biochem J 2003; 370: 1097-109.

44 Cheng $\mathrm{C}$, Tsuneyama K, Kominami R et al. Expression profiling of endogenous secretory receptor for advanced glycation end products in human organs. Mod Pathol 2005; 18: 1385-96.
45 Scudiero DA, Shoemaker RH, Paull KD et al. Evaluation of a soluble tetrazolium/formazan assay for cell growth and drug sensitivity in culture using human and other tumor cell lines. Cancer Res 1988; 48: 4827-33.

46 Yarrow JC, Perlman ZE, Westwood NJ, Mitchison TJ. A high-throughput cell migration assay using scratch wound healing, a comparison of imagebased readout methods. BMC Biotechnol 2004; 4: 21.

47 Rao NV, Argyle B, Xu X et al. Low anticoagulant heparin targets multiple sites of inflammation, suppresses heparin-induced thrombocytopenia, and inhibits interaction of RAGE with its ligands. Am J Physiol Cell Physiol 2010; 299: C97-110.

48 Icli F, Akbulut $\mathrm{H}$, Utkan $\mathrm{G}$ et al. Low molecular weight heparin (LMWH) increases the efficacy of cisplatinum plus gemcitabine combination in advanced pancreatic cancer. J Surg Oncol 2007; 95: 507-12.

49 Schiraldi M, Raucci A, Martínez ML et al. HMGB1 promotes recruitment of inflammatory cells to damaged tissues by forming a complex with CXCL12 and signaling via CXCR4. J Exp Med 2012; 209: 551-63

$50 \mathrm{Ma} \mathrm{L}$, Qiao $\mathrm{H}$, He C et al. Modulating the interaction of CXCR4 and CXCL12 by low-molecular-weight heparin inhibits hepatic metastasis of colon cancer. Invest New Drugs 2012; 30: 508-17. 